Historic, archived document

Do not assume content reflects current scientific knowledge, policies, or practices. 
Forest Service

Intermountain

Research Note INT-354

January 1986

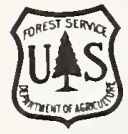

\title{
Susceptibility of Pine Populations to Western Gall Rust-Central Idaho
}

\author{
R. J. Hoff ${ }^{1}$
}

\begin{abstract}
Differences among provenances of ponderosa pine were observed in response to infection by western gall rust. The average level of resistance was 21 percent and varied from 5 to 45 percent. Differences appeared to vary at random within the geographic study area. Several host responses were visible, and these are discussed in terms of their possible role as defense mechanisms.
\end{abstract}

KEYWORDS: western gall rust, host responses, provenances

Rust fungi are among the most destructive pathogens of cultivated plants. Nearly every agronomic breeding program includes resistance to one or more rusts. Without continued vigilance to maintain, improve, or develop new rust-resistant varieties, crop losses would be prohibitive.

Most, if not all, of the pines of the world are susceptible to one or several rust fungi of the genera Cronartium, Endocronartium, or Peridermium. In situations where the host trees grow naturally, destruction by these fungi is minimal and economically unimportant. But, as in agronomic crops, tree cultivation causes a disturbance of natural ecosystems which alters the habitat and in many cases causes an increase in damage by tree rusts. The classic case in forestry is the Cronartium fusiforme:Pinus taeda, Pinus elliottii interaction that has caused serious losses (Siggers and Lindgren 1947). Fusiform rust resistance has become an important and expensive requirement in intensive management programs of these important timber species.
Western gall rust caused by Endocronartium harknessii is potentially a serious disease of many pines throughout most of North America (Peterson 1967). Two important timber species in the Northern Rockies, lodgepole pine (Pinus contorta) and ponderosa pine (Pinus ponderosa), are susceptible to this rust. Presently, western gall rust-caused damage, aside from localized stands, is mainly a management concern in plantations and seed orchards (Martinsson 1980). Some practices associated with intensive forest management, like replanting, áre likely to result in an increase in this disease. It is imperative, therefore, to secure knowledge about the biological dynamics of these rust:pine systems before the natural environment is badly disturbed. Knowledge of the kinds and levels of host responses relative to locations of the provenances, and how the rust varies with provenance and pine host, would aid the forest manager in the transfer of seed and in the selection of better timber types.

Variation among provenances, together with some information on host responses, has been reported for both lodgepole and ponderosa pine (Martinsson 1980; Thomas and Hart 1983). In addition, host responses on various pines infected by western gall rust have been reported (Hutchinson 1935; York 1938; Nelson 1972; Hiratsuka and Maruyama 1983). This paper reports on variation among populations of ponderosa pine from central Idaho in response to artificial inoculation by western gall rust.

\section{MATERIALS AND METHODS}

Seeds from 39 populations from central Idaho (fig. 1, table 1) were sown in 10-in ${ }^{3}$ containers in May of 1981 . The seedlings were grown and overwintered in a shadehouse at the Forestry Sciences Laboratory, Moscow, ID. During the summer, the seedlings were watered and lightly fertilized with the objective of producing seedlings that are not stressed but without accelerating their growth. During the winter, the seedlings were set on the ground within a screened cage to protect them from large accumulations of ice and snow. Bases were surrounded with sawdust so the roots would not freeze. 


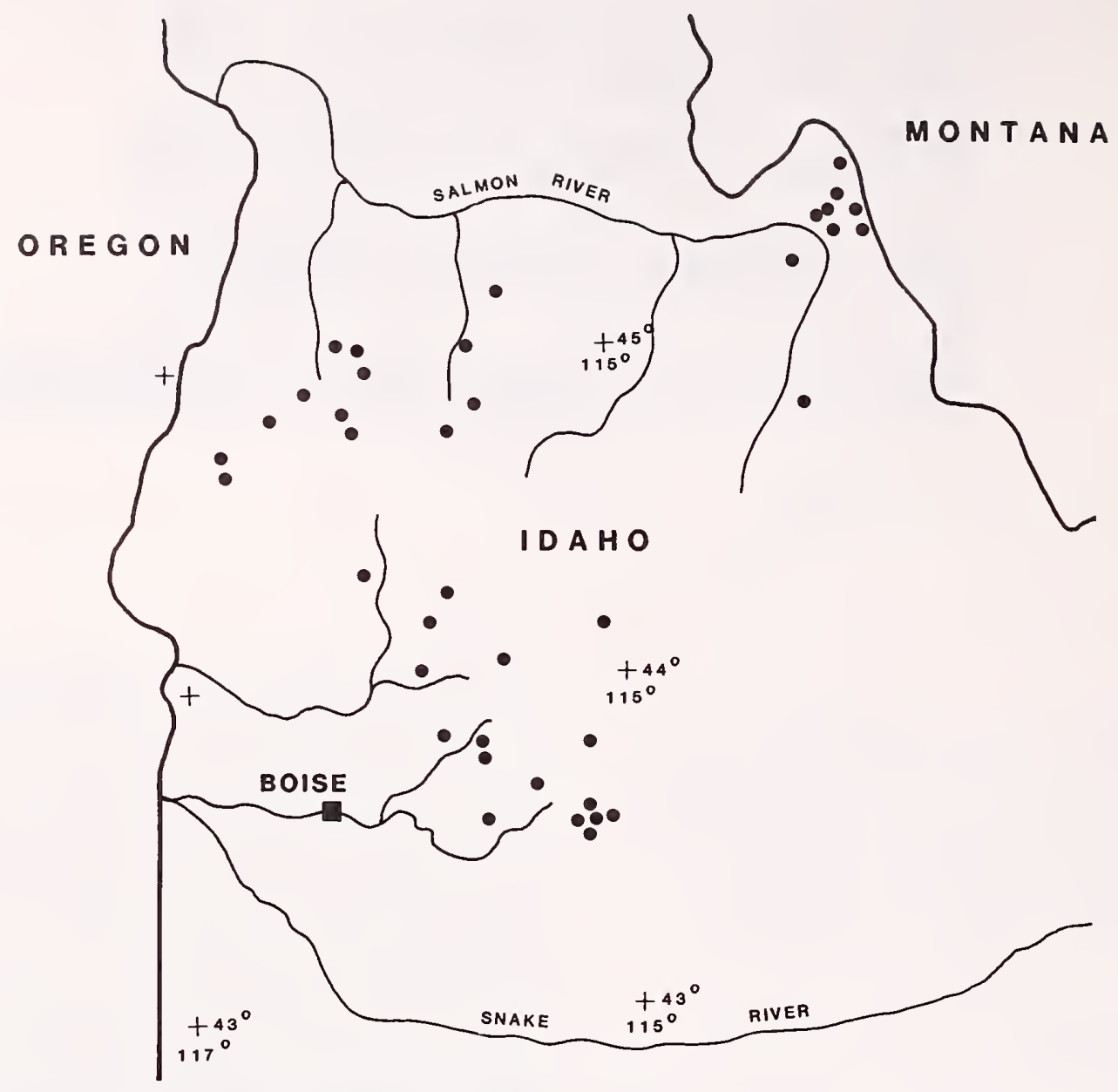

Figure 1.-Location of populations of ponderosa pine

included in this test.

The following spring, the seedlings were put back on benches in the shadehouse. In May of 1982, when the needles were just beginning to break out of the fascicle sheaths, the seedlings were moved into a mist chamber in preparation for inoculation. Mist nozzles operated so that a fog was constantly visible throughout the chamber. Twenty-four hours later, the stems of the seedlings were wet down and allowed to set for 1 hour to remove excess moisture. At this point, the seedlings were ready to inoculate.

\section{Experimental design:}

39 provenances

3 replications

7 seedlings/replication

Sixty-three seedlings randomly selected from all provenances served as uninoculated comparison trees.

Fresh inoculum was collected from at least 50 galls from a young lodgepole pine stand located in the Moose Creek drainage (lat. $46^{\circ} 51^{\prime}$ N., long. $116^{\circ} 23^{\prime} \mathrm{W}$., elevation 2,900 ft) about 3 miles west of Bovill, ID. Inoculation was accomplished by blowing spores over the seedlings using an air-sprayer adapted from an
Erlenmeyer flask. Each replication was inoculated separately with a mixture of $355 \mathrm{mg}$ of aeciospores and $2 \mathrm{~g}$ of talc. This gave a spore-to-seedling ratio of about 30,000 to 1 . The seedlings were maintained in the mist chamber for 72 hours, again with a constant, visible fog. The mist nozzles were then turned off and the seedlings allowed to slowly dry. When dry, the seedlings were moved back to the shadehouse. Frequent inspections for signs of rust infection were made throughout the summer. Data concerning presence of galls and bark reactions were taken each spring and fall.

In September, the seedlings were moved to Priest River Experimental Forest and planted at a spacing of 6 by 6 inches. The seven seedlings from each population per replication were planted in row plots. The comparison trees (three rows of seven trees per replication) were evenly spaced within the replication.

Analysis of variance and the associations of geographic patterns with infection were completed using SAS programs (SAS 1982). Provenance means (percent nongalled) were transformed to arcsin $\sqrt{\text { percent }}$ (Steel and Torrie 1960). Values of 0 percent or 100 percent were assigned values of $1 / 4 \mathrm{n}$ and $100-1 / 4 \mathrm{n}$, respectively (Steel and Torrie 1960). 
Table 1.-Location and host responses of seedlings of ponderosa pine inoculated with western gall rust

\begin{tabular}{|c|c|c|c|c|c|c|c|c|c|c|c|}
\hline \multirow[b]{2}{*}{ Stand } & \multirow[b]{2}{*}{$\begin{array}{c}\text { Eleva. } \\
\text { tion }\end{array}$} & \multirow[b]{2}{*}{ Latitude } & \multirow[b]{2}{*}{ Longitude } & \multicolumn{4}{|c|}{ Non-galled } & \multicolumn{4}{|c|}{ Galls present } \\
\hline & & & & $\begin{array}{c}\text { No } \\
\text { symp- } \\
\text { toms }\end{array}$ & $\begin{array}{c}\text { Red } \\
\text { spots } \\
\text { and } \\
\text { streaks }\end{array}$ & $\begin{array}{l}\text { Necrotic } \\
\text { tissue }\end{array}$ & Total & $\begin{array}{l}\text { Rate }^{1} \\
\text { of } \\
\text { appear- } \\
\text { ance }\end{array}$ & Number ${ }^{2}$ & $\begin{array}{l}\text { Dead }^{3} \\
\text { rust }\end{array}$ & $\begin{array}{c}\text { Total } \\
\text { infected }\end{array}$ \\
\hline & Feet & ${ }^{\circ} \mathrm{N}$ & ${ }^{\circ} W$ & \multicolumn{6}{|c|}{--------_---_---- Percent --_-_nn-n-_--_ } & \multicolumn{2}{|c|}{--- Percent --- } \\
\hline 1 & 6,000 & $44-57$ & $114-20$ & 10 & 5 & 5 & 19 & 34 & 2.4 & 24 & 51 \\
\hline 2 & 4,400 & $45-30$ & $113-55$ & 0 & 14 & 19 & 33 & 72 & 2.5 & 43 & 67 \\
\hline 3 & 6,150 & $45-30$ & $114-10$ & 5 & 0 & 5 & 10 & 40 & 3.7 & 47 & 90 \\
\hline 4 & 5,720 & $45-27$ & $114-13$ & 5 & 20 & 0 & 25 & 32 & 3.2 & 53 & 75 \\
\hline 5 & 5,400 & $45-27$ & $114-13$ & 0 & 5 & 10 & 15 & 84 & 3.3 & 35 & 85 \\
\hline 6 & 4,680 & $45-25$ & $114-11$ & 0 & 14 & 10 & 24 & 62 & 3.7 & 56 & 76 \\
\hline 7 & 4,700 & $43-51$ & $115-53$ & 5 & 6 & 11 & 11 & 68 & 3.2 & 75 & 89 \\
\hline 8 & 5,200 & $44-19$ & $116-14$ & 0 & 5 & 24 & 29 & 67 & 2.9 & 53 & 71 \\
\hline 9 & 6,000 & $44-47$ & $115-52$ & 5 & 19 & 5 & 29 & 68 & 3.2 & 40 & 71 \\
\hline 10 & 4,100 & $44-40$ & $116-52$ & 0 & 29 & 14 & 43 & 91 & 3.1 & 33 & 57 \\
\hline 11 & 6,000 & $43-48$ & $115-43$ & 0 & 5 & 24 & 29 & 73 & 2.6 & 27 & 71 \\
\hline 12 & 4,400 & $45-03$ & $116-23$ & 5 & 2 & 7 & 14 & 55 & 3.2 & 17 & 86 \\
\hline 13 & 3,700 & $44-54$ & $116-29$ & 0 & 0 & 5 & 5 & 61 & 3.3 & 22 & 95 \\
\hline 14 & 4,200 & $45-03$ & $116-16$ & 0 & 10 & 5 & 15 & 44 & 2.8 & 59 & 85 \\
\hline 15 & 4,400 & $44-59$ & $116-13$ & 0 & 0 & 5 & 5 & 44 & 4.1 & 50 & 95 \\
\hline 16 & 5,500 & $43-44$ & $115-27$ & 5 & 13 & 0 & 18 & 63 & 3.2 & 52 & 82 \\
\hline 17 & 4,000 & $44-18$ & $115-52$ & 5 & 5 & 20 & 30 & 73 & 2.7 & 43 & 70 \\
\hline 18 & 3,100 & $44-04$ & $115-56$ & 0 & 0 & 5 & 5 & 43 & 3.2 & 42 & 95 \\
\hline 19 & 4,300 & $44-53$ & $115-42$ & 5 & 15 & 25 & 45 & 64 & 2.5 & 45 & 55 \\
\hline 20 & 4,800 & $45-07$ & $115-45$ & 0 & 15 & 7 & 22 & 77 & 3.2 & 43 & 78 \\
\hline 21 & 5,800 & $43-37$ & $115-17$ & 0 & 0 & 5 & 5 & 80 & 3.7 & 50 & 95 \\
\hline 22 & 4,300 & $43-37$ & $115-43$ & 0 & 14 & 19 & 33 & 39 & 3.5 & 57 & 67 \\
\hline 23 & 4,100 & $43-50$ & $115-43$ & 0 & 5 & 0 & 5 & 36 & 3.1 & 50 & 95 \\
\hline 24 & 4,400 & $43-50$ & $115-22$ & 10 & 18 & 10 & 38 & 62 & 2.6 & 46 & 62 \\
\hline 25 & 5,100 & $44-11$ & $115-13$ & 5 & 5 & 0 & 10 & 37 & 3.7 & 47 & 90 \\
\hline 26 & 4,100 & $44-07$ & $115-37$ & 0 & 9 & 5 & 14 & 90 & 2.6 & 50 & 86 \\
\hline 27 & 3,400 & $44-13$ & $115-50$ & 0 & 14 & 0 & 14 & 37 & 3.1 & 56 & 86 \\
\hline 28 & 4,600 & $44-55$ & $116-40$ & 0 & 5 & 19 & 24 & 41 & 2.5 & 31 & 76 \\
\hline 29 & 5,800 & $44-42$ & $116-40$ & 0 & 19 & 14 & 33 & 76 & 3.7 & 64 & 67 \\
\hline 30 & 4,700 & $44-48$ & $116-17$ & 5 & 5 & 0 & 10 & 65 & 3.0 & 26 & 90 \\
\hline 31 & 6,200 & $45-15$ & $115-37$ & 0 & 9 & 5 & 14 & 56 & 4.3 & 33 & 86 \\
\hline 32 & 4,700 & $43-37$ & $115-14$ & 0 & 5 & 20 & 25 & 72 & 2.6 & 53 & 75 \\
\hline 33 & 4,600 & $43-37$ & $115-13$ & 5 & 11 & 5 & 21 & 36 & 3.1 & 73 & 79 \\
\hline 34 & 4,600 & $43-35$ & $115-14$ & 0 & 5 & 5 & 10 & 44 & 3.6 & 67 & 90 \\
\hline 35 & 5,000 & $43-36$ & $115-04$ & 0 & 0 & 14 & 14 & 33 & 3.8 & 11 & 86 \\
\hline 36 & 5,300 & $44-48$ & $116-17$ & 0 & 9 & 5 & 14 & 61 & 3.3 & 22 & 86 \\
\hline 37 & 5,600 & $45-19$ & $114-20$ & 5 & 4 & 10 & 19 & 50 & 3.7 & 41 & 81 \\
\hline 38 & 5,600 & $45-38$ & $114-00$ & 5 & 27 & 11 & 43 & 62 & 3.5 & 38 & 57 \\
\hline 39 & 5,900 & $47-27$ & $113-58$ & 0 & 9 & 24 & 33 & 62 & 3.2 & 43 & 67 \\
\hline Average & & & & 2 & 9 & 10 & 21 & 58 & 3.2 & 44 & 79 \\
\hline
\end{tabular}

${ }^{1}$ Ratio of galls appearing at 4 months to 28 months after inoculation.

${ }^{2}$ Galls per infected seedlings.

${ }^{3}$ Infected seedlings that died. 


\section{RESULTS}

Several host reactions were observed.

1. Red spots, streaks, and blotches on stems within a month of inoculation.

2. Small dead patches on the stems within 2 months of inoculation (fig. 2).

3. Small swellings and bumps indicating incipient galls within 4 months of inoculation (fig. 3 ).

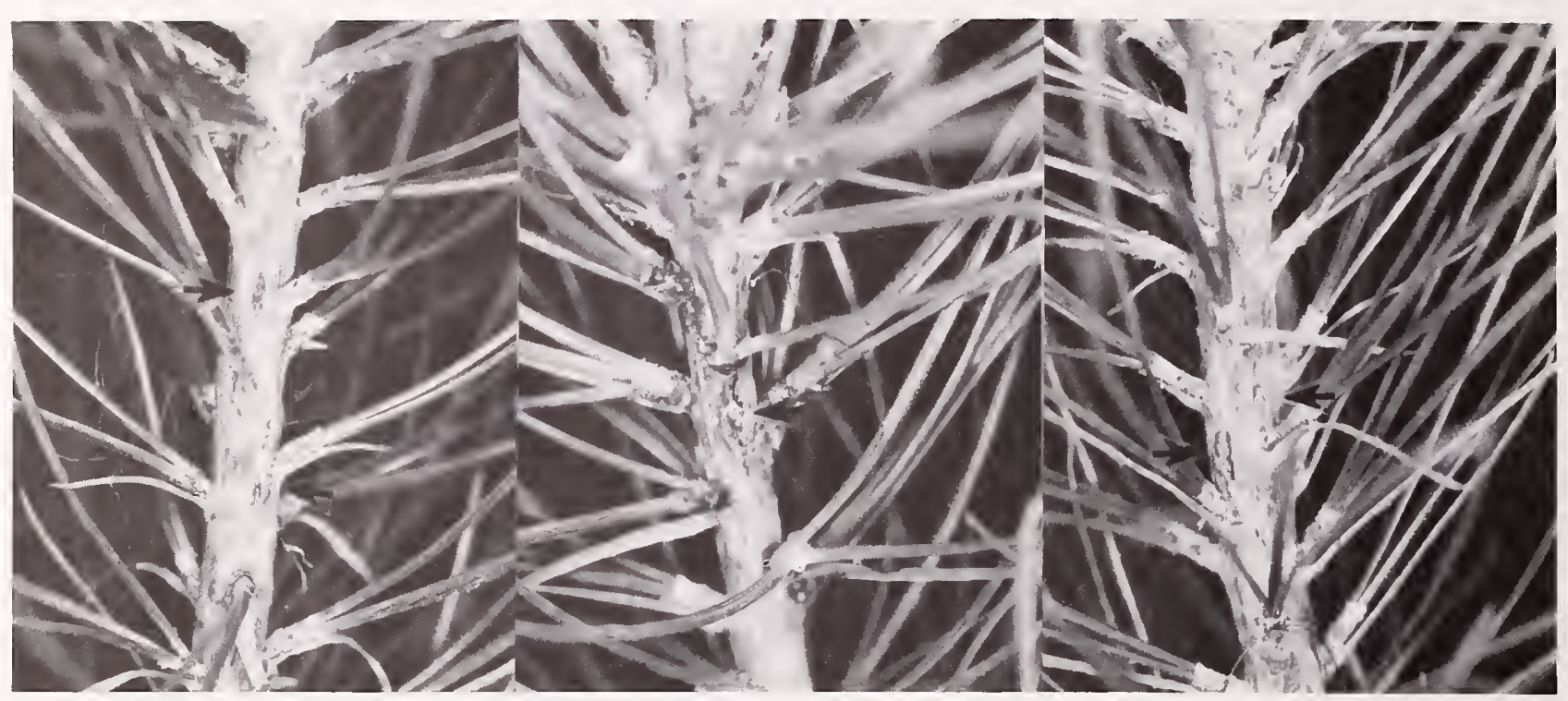

Figure 2.-Small necrotic areas (arrows) on the stems of ponderosa pines

2 months after inoculation with western gall rust.
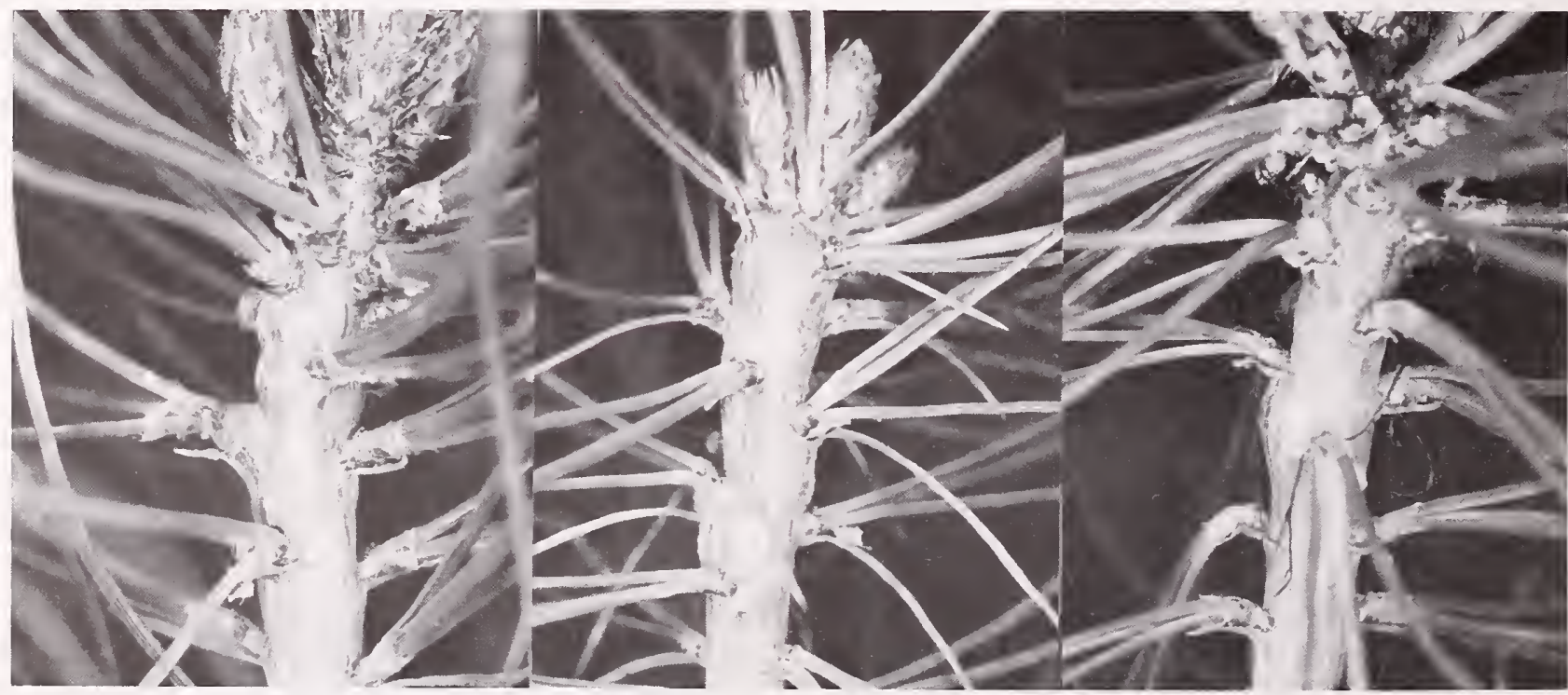

Figure 3.-Incipient galls of western gall rust on seedlings of ponderosa pine 4 months after inoculation. 
4. Large, dead patches on the stem that increased in size from 4 to 28 months after inoculation (fig. 4). Some of these reactions were so severe that they caused malformation of the seedling (fig. 5).

5. Collapse and death of galls.

6. Variation in size of galls (fig. 6).

Out of 819 trees inoculated, only 17 had no symptoms (table 1). None of the 98 control seedlings had symptoms.

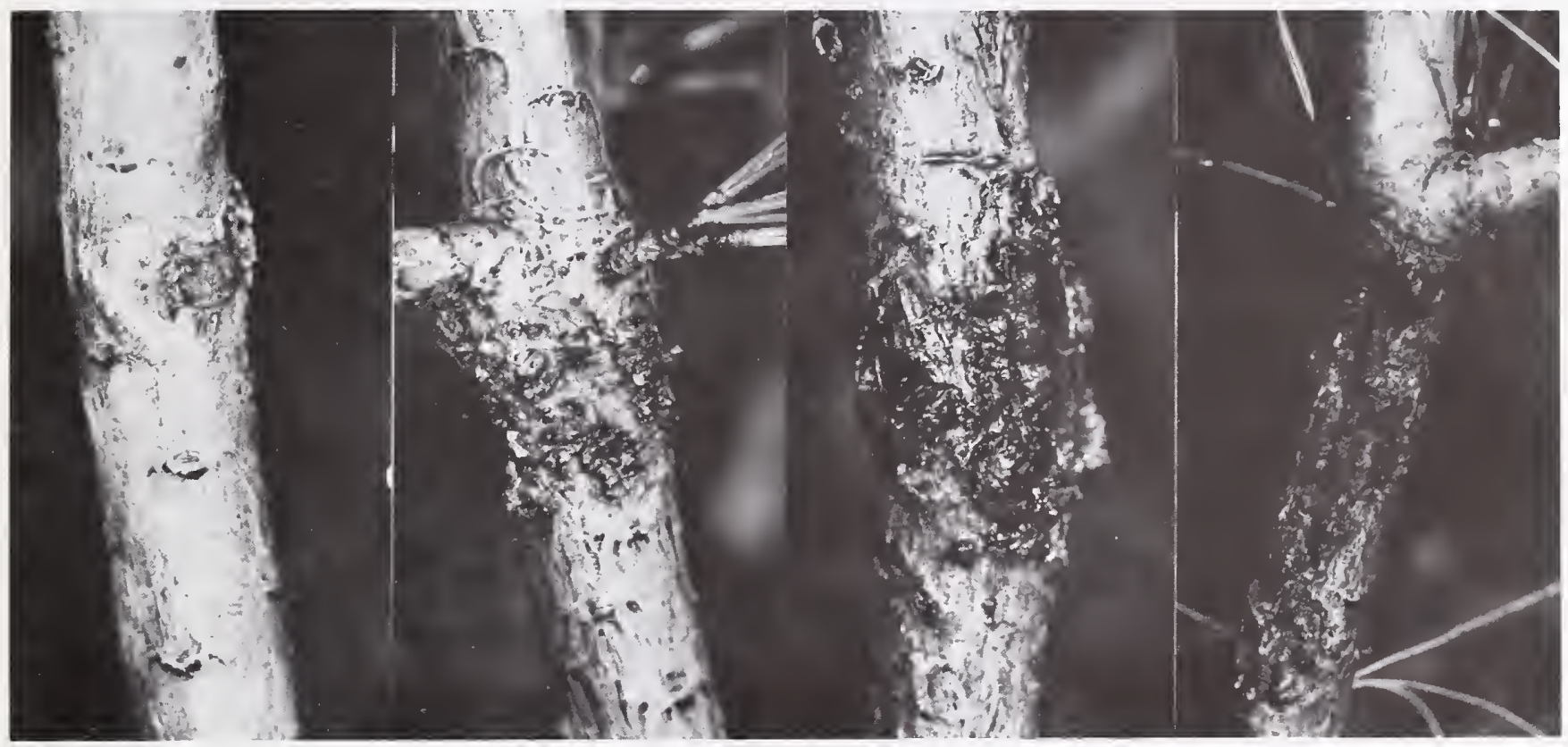

Figure 4.-Large necrotic areas on the stems of ponderosa pines 4 to 12 months after inoculation.

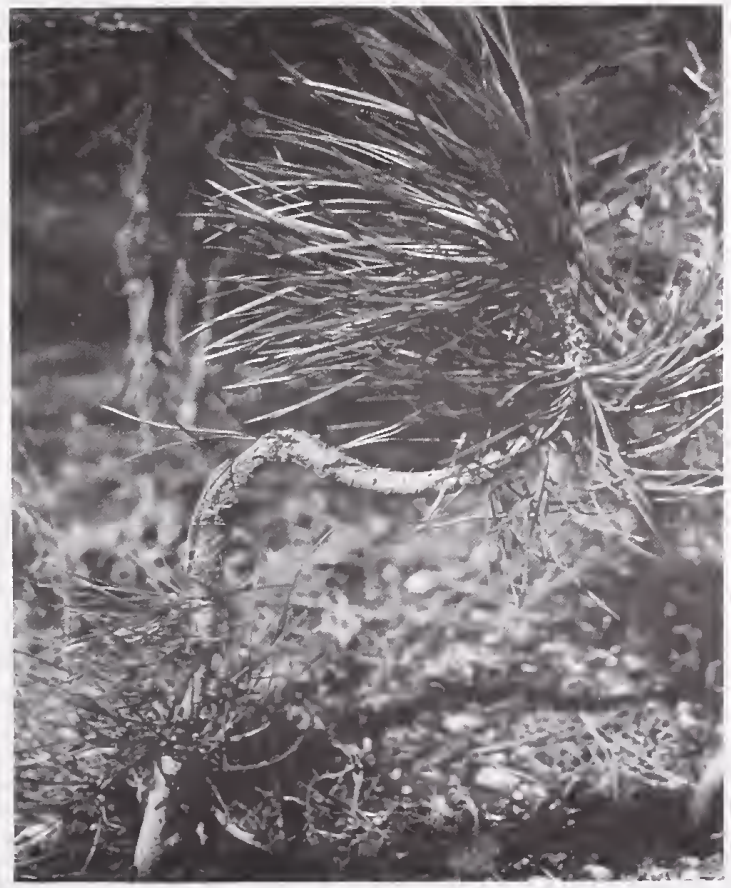

Figure 5.-Malformed seedling caused by many bark reactions. 


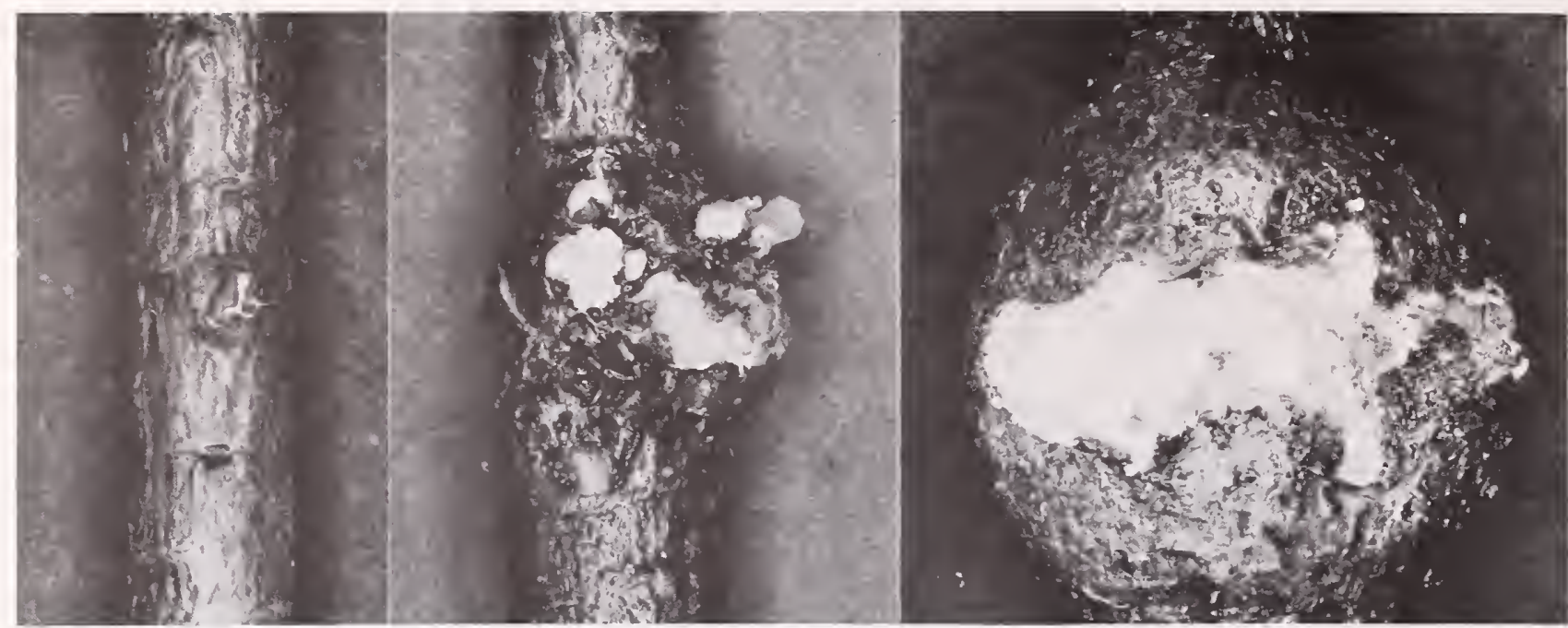

Figure 6.-Variation in size of galls of western gall rust on ponderosa pines.

The percentage of seedlings without galls (that is, with evidence of resistance) was 21 percent. This ranged from 5 to 45 percent among populations (table 1). These means were significantly different at the 2 percent level (table 2).

Of the nongalled seedlings, 10 percent $(2$ percent verall) had no symptoms; 42 percent (9 percent overall) exhibited red spots, streaks, or blotches on the stem; and 48 percent (10 percent overall) had dead patches of various sizes on the stem, or had developed a gall (table 1).

The percentages of nongalled seedlings by population were plotted against elevation, latitude, and longitude. The $R^{2}$ values were $0.02,0.03$, and 0.01 , respectively. The percentages of nongalled appear to be random (table 1) for these factors.

Table 2.-Analysis of variance of transformed means of seedlings without galls from 39 populations of ponderosa pine

\begin{tabular}{lcccc}
\hline & $\begin{array}{c}\text { Degrees of } \\
\text { freedom }\end{array}$ & $\begin{array}{c}\text { Mean } \\
\text { square }\end{array}$ & $F$ & $\begin{array}{c}\text { Probability } \\
>\text { F }\end{array}$ \\
\hline Block & 2 & 0.121 & 2.95 & 0.057 \\
Population & 38 & .072 & 1.76 & .017 \\
Block $\times$ population & 76 & .041 & & \\
\hline
\end{tabular}

Fifty-eight percent of the galls that were present at 28 months first appeared at 4 months (table 1). This varied among the populations from 32 to 91 percent.

Probability of a higher $F$ value for differences among the population means was 0.15 . And the $\mathrm{R}^{2}$ values for elevation, latitude, and longitude were essentially zero.

The percentage of infected trees in the population that had died by 28 months after inoculation averaged 44 percent, ranging from 11 to 73 percent (table 1). Probability of a higher $F$ value was 0.23 , and there were no associations with elevation, latitude, or longitude.

\section{DISCUSSION}

It is rare to find natural stands of ponderosa pine severely damaged by western gall rust in the Northern Rocky Mountains. And yet, in this test, 79 percent of the seedlings were infected, and nearly half of those were dead within 28 months after inoculation. The cause was probably the high spore density applied under optimal conditions - a situation not likely to occur very often in nature. Rust infection most frequently occurs in wave years (Leaphart 1955; Peterson 1959). Years that are foggy with intermittent showers during the high spore production time would seem to be ideal.

High resistance does not seem to be necessary in maintaining natural balance with this host-pest system. The probability of high spore density, coupled with optimal environmental conditions, may be quite low. In working out an artificial inoculation procedure, I found that a visible fog was not enough. I had to make sure the stems of the seedlings were wet. This method provided just the right conditions. These conditions may not occur in nature very often.

Even though the total level of resistance was only 21 percent, the rich assortment of host responses suggests that there are several defense mechanisms and, consequently, many genes involved.

\section{Signs of Defense Mechanisms}

1. No symptoms: Infection was so high that it is hard to believe that these seedlings had escaped infection. Resistance could be due to prevention of spore germination, formation of an effective barrier by the cuticle or epidermal cell walls, or destruction of the penetrating germ tube, which results in a very small host sign not readily visible.

2. Red spots, streaks, or blotches with no visible sign of necrotic stem patches or gall symptoms: This reaction was not severe enough to cause a visible necrotic patch on the stem, so presumably the fungus was either prevented from entering because the chemicals causing 
red coloration in that seedling possibly were toxic, or the fungus was destroyed soon after penetration, but the defense reaction was so severe or quick that no necrosis was observed.

3. Necrotic patches on the stem: These ranged from very small patches that would soon be overgrown or sloughed off, to very large patches, at times so severe that they caused seedlings to be malformed.

Hutchinson (1935) reported similar reactions in Pinus sylvestris infected with western gall rust. He found that the first type was a fairly quick response by the host that killed the fungus, but the more severe reactions were often typified as a seesaw reaction by host and fungus: the host produced a wound periderm, then the fungus broke through, then the host would produce another periderm, and so on, until either the host or the fungus succumbed, or they both lived in some kind of a physiological balance.

4. Gall death: This may just be an extension of the severe stem reactions. But in these cases, there were no early signs of a resistant host reaction.

5. Gall size: The galls in some seedlings were so small that very little damage would be expected.

6. Rate of gall appearance: Although this trait was nonsignificant in this provenance test, I expect that a family test may show that this is an important defense mechanism. Slow appearance and slow growth of the fungus would not likely result in causing much damage to the host.

7. Tolerance: This is the ability of infected seedlings to remain alive and, especially, to grow normally or close to normal. Again, this trait was nonsignificant in this provenance test.

Population differentiation appeared to vary randomly over the landscape. But because the degree of resistance is usually thought of as being a result of disease severity (Leppik 1970), why would geographically close stands have such large differences in resistance? One cause could be the varying and random probability of infection during regeneration; that is, conditions for inoculation appear quite demanding, so the probability of optimal conditions occurring when trees are most vulnerable to infection and damage (when young) are small. A test of individual families with varying levels of spore density using rust collections from several sources now seems extremely valuable.

\section{REFERENCES}

Hiratsuka, Y.; Maruyama, P. Resistant reactions of two Asian pines to western gall rust, Endocronartium harknessii. Phytopathology. 73: 835; 1983. Abstract.

Hutchinson, W. G. Resistance of Pinus sylvestris to a gall-forming peridermium. Phytopathology. 25: 819-843; 1935.

Leaphart, C. D. Preliminary observations on a current outbreak of western gall rust (Cronartium coleosporioides). Plant Disease. 39: 314-315; 1955.

Leppik, E. E. Gene centers of plants as sources of disease resistance. Annual Review of Phytopathology. 8: $323-344 ; 1970$.

Martinsson, O. Stem rusts in lodgepole pine provenance trials. Silvae Genetica. 29: 23-26; 1980.

Nelson, D. K. The ecology and pathology of pine gall rust in California. Berkeley: University of California; 1972. 160 p. Ph.D. dissertation.

Peterson, R. S. Geographic patterns in gall-rust infestation. In: Proceedings, 7 th western intermountain forest disease work conference; Pullman, WA. 1959: 48-51.

Peterson, R. S. The peridermium species on pine stems. Bulletin of the Torrey Botanical Club. 94: 511-542; 1967.

SAS Institute. SAS user's guide: statistics. Cary, NC: SAS Institute; 1982.584 p.

Siggers, P. V.; Lindren, R. M. An old disease-a new problem. Southern Lumberman. 175: 2201; 1947.

Steel, R. G. D.; Torrie, J. H. Principles and procedures of statistics. New York: McGraw-Hill; 1960. 481 p.

Thomas, C. S.; Hart, J. H. Severity of Endocronartium harknessii on Pinus ponderosa. Phytopathology 73: 838; 1983. Abstract.

York, H. H. Inoculation of trees with rusts. Phytopathology. 28: 210-212; 1938. 


\section{INTERMOUNTAIN RESEARCH STATION}

The Intermountain Research Station provides scientific knowledge and technology to improve management, protection, and use of the forests and rangelands of the Intermountain West. Research is designed to meet the needs of National Forest managers, Federal and State agencies, industry, academic institutions, public and private organizations, and individuals. Results of research are made available through publications, symposia, workshops, training sessions, and personal contacts.

The Intermountain Research Station territory includes Montana, Idaho, Utah, Nevada, and western Wyoming. Eighty-five percent of the lands in the Station area, about 231 million acres, are classified as forest or rangeland. They include grasslands, deserts, shrublands, alpine areas, and forests. They provide fiber for forest industries, minerals and fossil fuels for energy and industrial development, water for domestic and industrial consumption, forage for livestock and wildlife, and recreation opportunities for millions of visitors.

Several Station units conduct research in additional western States, or have missions that are national or international in scope.

Station laboratories are located in:

Boise, Idaho

Bozeman, Montana (in cooperation with Montana State University)

Logan, Utah (in cooperation with Utah State University)

Missoula, Montana (in cooperation with the University of Montana)

Moscow, Idaho (in cooperation with the University of Idaho)

Ogden, Utah

Provo, Utah (in cooperation with Brigham Young University)

Reno, Nevada (in cooperation with the University of Nevada)

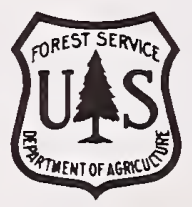

